\title{
Disodium Cromoglycate Attenuates Hypoxia Induced Enlargement of End-Expiratory Lung Volume in Rats
}

\author{
H. MAXOVÁ ${ }^{1}$, A. HEZINOVÁ ${ }^{1}$, M. VÍZEK ${ }^{1}$ \\ ${ }^{1}$ Department of Pathophysiology, Second Faculty of Medicine, Charles University in Prague and \\ Centre for Cardiovascular Research, Prague, Czech Republic
}

Received March 18, 2011

Accepted September 23, 2011

\begin{abstract}
Summary
Mechanism responsible for the enlargement of end-expiratory lung volume (EELV) induced by chronic hypoxia remains unclear. The fact that the increase in EELV persists after return to normoxia suggests involvement of morphological changes. Because hypoxia has been also shown to activate lung mast cells, we speculated that they could play in the mechanism increasing EELV similar role as in vessel remodeling in hypoxic pulmonary hypertension (HPH). We, therefore, tested an effect of mast cells degranulation blocker disodium cromoglycate (DSCG) on hypoxia induced EELV enlargement. Ventilatory parameters, EELV and right to left heart weight ratio $(\mathrm{RV} / \mathrm{LV}+\mathrm{S})$ were measured in male Wistar rats. The experimental group (H+DSCG) was exposed to 3 weeks of normobaric hypoxia and treated with DSCG during the first four days of hypoxia, control group was exposed to hypoxia only $(\mathrm{H})$, two others were kept in normoxia as non-treated $(\mathrm{N})$ and treated (N+DSCG) groups. DSCG treatment significantly attenuated the EELV enlargement $(H+D S C G=6.1 \pm 0.8$; $\mathrm{H}=9.2 \pm 0.9 ; \mathrm{ml} \pm \mathrm{SE}$ ) together with the increase in minute ventilation $(H+D S C G=190 \pm 8 ; \quad H=273 \pm 10 ; \quad \mathrm{ml} / \mathrm{min} \pm \mathrm{SE})$ and $R V / L V+S(H+D S C G=0.39 \pm 0.03 ; H=0.50 \pm 0.06)$.
\end{abstract}

\section{Key words}

Chronic hypoxia - End-expiratory lung volume - Tissue remodeling • Mast cells • Disodium cromoglycate

\section{Corresponding author}

Hana Maxová, Department of Pathophysiology, $2^{\text {nd }}$ Faculty of Medicine, Charles University in Prague, Plzeňská 221, 15000 Praha 5, Czech Republic.

E-mail: hana.maxova@lfmotol.cuni.cz
Chronic hypoxia and exposure to high altitude leads to the development of hypoxic pulmonary hypertension (HPH) characterized by increase of pulmonary arterial pressure, hypertrophy of the right heart and thickening of peripheral pulmonary vessels. Hypoxia concurrently increases the end-expiratory lung volume (EELV) (Barer et al. 1978). Although this increase has implications for mechanics of breathing (Barer et al. 1978, Vizek and Bonora 2001), its mechanism remains unclear. The fact that this enlargement persists after return to air breathing for weeks suggests that remodeling of the lung tissue rather than functional changes are involved. Hypoxia is known to induce increased activity of proteolytic enzymes as serine proteases and tissue metalloproteinases (Greenlee et al. 2007, Pejler et al. 2010), which has been shown to participate in remodeling of pulmonary vessels (Riley et al. 2000). It has been also shown that important source of proteolytic activity are pulmonary mast cells (Tozzi et al. 1998) and prevention of their degranulation attenuates vascular remodeling (Banasova et al. 2008). To test whether release of mast cells proteolytic enzymes is involved also in a mechanism responsible for EELV enlargement in chronic hypoxia, we decided to measure EELV changes in rats treated during hypoxic exposure by mast cell stabilizer DSCG. DSCG is compound which prevents mast cells degranulation and acts as antiinflammatory agent (Theoharides et al. 2000).

Studies were performed in 20 adult male Wistar rats (Konárovice, Czech Republic) in accordance with the European Community and NIH guidelines for using experimental animals. All procedures were approved by

PHYSIOLOGICAL RESEARCH • ISSN 0862-8408 (print) • ISSN 1802-9973 (online)

(c) 2011 Institute of Physiology v.v.i., Academy of Sciences of the Czech Republic, Prague, Czech Republic

Fax +420 241062 164, e-mail: physres@biomed.cas.cz,www.biomed.cas.cz/physiolres 
Table 1. Average body weight $(B W)$, minute ventilation $\left(V^{\prime}{ }_{E}\right)$ and right heart ventricle to left ventricle plus septum ratio $(R V / L V+S)$ in normoxic $(\mathrm{N})$ and hypoxic $(\mathrm{H})$ nontreated groups and normoxic (N+DSCG) and hypoxic (H+DSCG) groups treated with DSCG.

\begin{tabular}{lllll}
\hline Group & $\mathbf{n}$ & $\mathbf{B W}, \mathbf{g}$ & $\mathbf{V}_{\mathbf{E}}^{\prime}, \mathbf{m} \mathbf{m} / \mathbf{m i n}$ & $\mathbf{R V / L V + S}$ \\
\hline$N$ & 5 & $352 \pm 14$ & $183 \pm 7$ & $0.231 \pm 0.007$ \\
$N+D S C G$ & 5 & $379 \pm 6$ & $202 \pm 6$ & $0.253 \pm 0.007$ \\
$H$ & 5 & $391 \pm 10$ & $273 \pm 10^{*}$ & $0.496 \pm 0.057 * *$ \\
$H+D S C G$ & 5 & $367 \pm 7$ & $190 \pm 8$ & $0.386 \pm 0.02 *^{*}{ }^{\dagger}$ \\
\hline
\end{tabular}

* $\mathrm{p}<0.0001 \mathrm{H}$ group versus all groups; ** $\mathrm{p}<0.01 \mathrm{H}$ and $\mathrm{H}+\mathrm{DSCG}$ groups versus $\mathrm{N}$ and $\mathrm{N}+\mathrm{DSCG}$ groups; $+\mathrm{p}<0.05 \mathrm{H}+\mathrm{DSCG}$ group versus $\mathrm{H}$ group

our institution's Animal Studies Committee.

The experimental group (H+DSCG) was exposed to 3 weeks of normobaric hypoxia $\left(\mathrm{F}_{\mathrm{I}} \mathrm{O}_{2} 0.1\right)$ in a normobaric hypoxic chamber (Hampl and Herget 1990) and treated with disodium cromoglycate DSCG (Sigma Aldrich, Prague, Czech Republic) applied intraperitoneally (40 mg/kg b.w.) during the first four days of hypoxia. One control group was exposed to hypoxia only $(\mathrm{H})$, two others were kept in normoxia as non-treated $(\mathrm{N})$ and treated $(\mathrm{N}+\mathrm{DSCG})$ groups. All groups were tested on the $21^{\text {st }}$ day after the onset of experiment. $\mathrm{PCO}_{2}$, temperature and humidity in the hypoxic chamber were controlled and kept the same as for normoxic controls.

Measurement of ventilation and EELV was performed in animals anesthetized with an intraperitoneal injection of Thiopental (ICN Czech Republic, Roztoky, Czech Republic; $40 \mathrm{mg} / \mathrm{kg} /$ b.w.). They were intubated and placed in a whole body plethysmograph (Maxova and Vizek 2001). A tracheal cannula (ID $1.7 \mathrm{~mm}$, OD $2.3 \mathrm{~mm}$ ) was connected to an outer circuit ventilated with air. A specially designed computer program was used to calculate the rate of breathing, tidal volume, minute ventilation and EELV (Maxova and Vizek 2002). EELV was calculated from the changes in tracheal pressure and lung volume after the occlusion of the tracheal tube at the end of expiration. Rats were then overdosed with Thiopental and the hearts were removed from the chest. The right heart ventricle (RV) and the left ventricle plus septum $(\mathrm{LV}+\mathrm{S})$ were separated and weighed. $\mathrm{RV} / \mathrm{LV}+\mathrm{S}$ ratio was used as a marker of $\mathrm{HPH}$.

Each ventilatory variable was averaged over six consecutive respiratory cycles. EELV values are the mean of three measurements. The results are presented as means \pm SE. ANOVA with Fischer's PLSD test was used for statistical evaluation of the data, $p<0.05$ was considered as significant.
The average body weights (BW), minute ventilation $\left(\mathrm{V}_{\mathrm{E}}^{\prime}\right)$ and right heart ventricle to left ventricle plus septum ratio $(\mathrm{RV} / \mathrm{LV}+\mathrm{S})$ are summarized in Table 1. Higher ventilation in group $\mathrm{H}$ was only due to increase in tidal volume, rate of breathing was similar in all groups (ANOVA, $\mathrm{p}=0.06$ ).

Administration of DSCG did not affect EELV of animals kept in air. Exposure to chronic hypoxia increased EELV, but significantly less in the DSCG treated (H+DSCG group) than in the non-treated (H group) rats (Fig. 1).

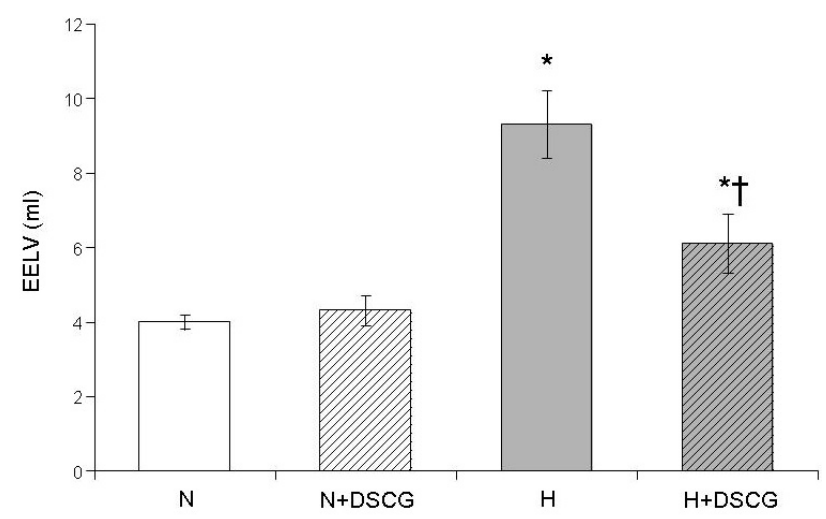

Fig. 1. End-expiratory lung volume (EELV, $\mathrm{ml})$ in normoxic (N) and hypoxic $(\mathrm{H})$ nontreated groups (unshaded) and DSCG treated (N+DSCG, H+DSCG) groups (shaded). * $\mathrm{p}<0.05 \mathrm{H}$ and $\mathrm{H}+\mathrm{DSCG}$ groups versus $\mathrm{N}$ group; $+\mathrm{p}<0.05 \mathrm{H}+\mathrm{DSCG}$ group versus $\mathrm{H}$ group

The main finding of our study is that prevention of mast cell degranulation at the onset of exposure to chronic hypoxia significantly attenuated EELV enlargement in chronic hypoxia.

To prevent release of substances from mast cells we used disodium cromoglycate (DSCG) in the same dose as in our previous experiments (Banasova et al. 2008, Maxova et al. 2010). We applied DSCG only 
during the first four days of hypoxic exposure, because the initial phase of hypoxia is for the remodeling of the lung tissue crucial (Chovanec et al. 2009, Lachmanova et al. 2005). Administration of DSCG in early phase of hypoxia has effect on vascular remodeling. Histology revealed significantly decrease percentage of double laminated peripheral pulmonary vessels in DSCG treated group, gel electrophoresis of collagen showed less collagen fragments in extracts from peripheral pulmonary arteries (Banasova et al. 2008).

EELV increases could be classified as dynamic or static hyperinflation (Palecek 2001). Because components of dynamic hyperinflation - airway resistance, breathing frequency and postinspiratory activity of the diaphragm (DE) - in chronic normobaric hypoxia decrease (Habre et al. 2010) or do not differ from that of controls (breathing frequency - our results; DE - Vizek and Bonora (2001)) dynamic increase in EELV is not likely.

Hypoxia has been shown to induce the release of wide variety of proteolytic enzymes and growth factors in particular from lung mast cells (Maxova et al. 2008, Thakker-Varia et al. 1998). Enhanced collagenolytic activity in tissue (Novotná and Herget 1998, Riley et al. 2000) may result in an increase of the lung compliance (component of static hyperinflation). However, increased lung compliance was found only in newborn rats exposed to 6 days of hypoxia (Okubo and Mortola 1989), while others did not find in chronic hypoxia any increase in compliance (Barer et al. 1978) or decrease in elastance (Habre et al. 2010). Hypoxia may also trigger growth (Sekhon et al. 1995) and/or remodeling of the lungs similar to that seen during development of HPH. Estrada and Chesler (Estrada and Chesler 2009) have recently shown collagen-related gene and protein expression changes in lungs of chronically hypoxic mice.

We cannot outline the mechanism increasing EELV in chronic hypoxia, however the fact that it involves mast cells degranulation brings new aspect of the problem. Interestingly enough the similarity in effects of blocking of mast cells degranulation on increases in pulmonary blood pressure and EELV in chronic hypoxia suggests that mechanisms responsible for these changes are interconnected.

\section{Conflict of Interest}

There is no conflict of interest.

\section{Acknowledgements}

This work was supported by grants from the Grant Agency of the Czech Republic (305/08/0108), and from the Cardiovascular Research Centre (MSMT 1M0510).

\section{References}

BANASOVA A, MAXOVA H, HAMPL V, VIZEK M, POVYSILOVA V, NOVOTNA J, VAJNEROVA O, HNILICKOVA O, HERGET J: Prevention of mast cell degranulation by disodium cromoglycate attenuates the development of hypoxic pulmonary hypertension in rats exposed to chronic hypoxia. Respiration 76: 102-107, 2008.

BARER GR, HERGET J, SLOAN PJ, SUGGETT AJ: The effect of acute and chronic hypoxia on thoracic gas volume in anaesthetized rats. $J$ Physiol 277: 177-192, 1978.

CHOVANEC M, NOVOTNA J, WILHELM J, HAMPL V, VIZEK M, HERGET J: Hypercapnia attenuates hypoxic pulmonary hypertension by inhibiting lung radical injury. Physiol Res 58: S79-S85, 2009.

ESTRADA KD, CHESLER NC: Collagen-related gene and protein expression changes in the lung in response to chronic hypoxia. Biomech Model Mechanobiol 8: 263-272, 2009.

GREENLEE KJ, WERB Z, KHERADMAND F: Matrix metalloproteinases in lung: multiple, multifarious, and multifaceted. Physiol Rev 87: 69-98, 2007.

HABRE W, JANOSI TZ, FONTAO F, MEYERS C, ALBU G, PACHE JC, PETAK F: Mechanisms for lung function impairment and airway hyperresponsiveness following chronic hypoxia in rats. Am J Physiol Lung Cell Mol Physiol 298: L607-L614, 2010.

HAMPL V, HERGET J: Perinatal hypoxia increases hypoxic pulmonary vasoconstriction in adult rats recovering from chronic exposure to hypoxia. Am Rev Respir Dis 142: 619-624, 1990.

LACHMANOVA V, HNILICKOVA O, POVYSILOVA V, HAMPL V, HERGET J: N-acetylcysteine inhibits hypoxic pulmonary hypertension most effectively in the initial phase of chronic hypoxia. Life Sci 77: 175-182, 2005. 
MAXOVA H, NOVOTNA J, VAJNER L, TOMASOVA H, VYTASEK R, VIZEK M, BACAKOVA L, VALOUSKOVA V, ELIASOVA T, HERGET $\mathrm{J}$ : In vitro hypoxia increases production of matrix metalloproteinases and tryptase in isolated rat lung mast cells. Physiol Res 57: 903-910, 2008.

MAXOVA H, VASILKOVA M, NOVOTNA J, VAJNEROVA O, BANASOVA A, VIZEK M, HERGET J: Prevention of mast cell degranulation by disodium cromoglycate delayed the regression of hypoxic pulmonary hypertension in rats. Respiration 80: 335-339, 2010.

MAXOVA H, VIZEK M: Ventilatory response to sustained hypoxia in carotid body denervated rats. Physiol Res 50: 327-331, 2001.

MAXOVA H, VIZEK M: Hypercapnia does not affect functional residual capacity enlargement induced by chronic hypoxia. Physiol Res 51: 537-540, 2002.

NOVOTNÁ J, HERGET J: Exposure to chronic hypoxia induces qualitative changes of collagen in the walls of peripheral pulmonary arteries. Life Sci 62: 1-12, 1998.

OKUBO S, MORTOLA JP: Respiratory mechanics in adult rats hypoxic in the neonatal period. J Appl Physiol 66: 1772-1778, 1989.

PALECEK F: Hyperinflation: control of functional residual lung capacity. Physiol Res 50: 221-230, 2001.

PEJLER G, RONNBERG E, WAERN I, WERNERSSON S: Mast cell proteases: multifaceted regulators of inflammatory disease. Blood 115: 4981-4990, 2010.

RILEY DJ, THAKKER-VARIA S, WILSON FJ, POIANI GJ, TOZZI CA: Role of proteolysis and apoptosis in regression of pulmonary vascular remodeling. Physiol Res 49: 577-585, 2000.

SEKHON HS, WRIGHT JL, THURLBECK WM: Pulmonary function alterations after 3 wk of exposure to hypobaria and/or hypoxia in growing rats. J Appl Physiol 78: 1787-1792, 1995.

THAKKER-VARIA S, TOZZI CA, POIANI GJ, BABIARZ JP, TATEM L, WILSON FJ, RILEY DJ: Expression of matrix-degrading enzymes in pulmonary vascular remodeling in the rat. Am J Physiol 275: L398-L406, 1998.

THEOHARIDES TC, WANG L, PANG X, LETOURNEAU R, CULM KE, BASU S, WANG Y, CORREIA I: Cloning and cellular localization of the rat mast cell $78-\mathrm{kDa}$ protein phosphorylated in response to the mast cell "stabilizer" cromolyn. J Pharmacol Exp Ther 294: 810-821, 2000.

TOZZI CA, THAKKER-VARIA S, YU SY, BANNETT RF, PENG BW, POIANI GJ, WILSON FJ, RILEY DJ: Mast cell collagenase correlates with regression of pulmonary vascular remodeling in the rat. Am J Respir Cell Mol Biol 18: 497-510, 1998.

VIZEK M, BONORA M: Ventilation, EELV and diaphragmatic activity in rats during chronic normobaric hypoxia. Respir Physiol 128: 147-159, 2001. 